\title{
Phosphorus Forms Related to Sediment Grain Size and Geochemical Characteristics in French Coastal Areas
}

\author{
F. Andrieux-Loyer and A. Aminot
}

\begin{abstract}
:
Phosphorus forms with respect to sediment characteristics, such as grain-size, and major chemical elements, were studied in French coastal marine areas (the Bay of Seine and the Loire and Gironde Estuaries).

In the three areas, Fe/Al-bound phosphate (Fe/Al-P) and exchangeable phosphate (exch-P) were significantly related to the proportion of fine fraction $(<63 \mu \mathrm{m})$. The special association of these forms with fine particles, as well as the relationships between exch-P, Fe/Al-P and Fe showed that adsorption processes on Fe oxides had taken place. However, for similar Fe concentrations, Bay of Seine sediments showed Fe/Al-P concentrations which were four to five times higher than those found in the Loire and Gironde Estuaries. This was attributed to differences in sediment nature and processes in these two types of areas. Indeed, the Loire and Gironde Estuaries frequently show hypoxia.
\end{abstract}

Calcium-bound phosphate (Ca-P) was found in all grain size classes with comparable concentrations in the Bay of Seine where there was no correlation between Ca-P and $\mathrm{Ca}$. This corresponded to the calcium's marine origin (shells) in the Bay of Seine. In contrast, the correlation of Ca-P with $\mathrm{Ca}$ and the fine fraction of the sediment in the Loire and Gironde Estuaries was characteristic of the predominant metamorphic origin of $\mathrm{Ca}-\mathrm{P}$ in these areas.

Useful information for interpretation of P-forms can be obtained from major sediment characteristics. Thus, for areas where specific relationships have previously been established good estimates of Pforms could be predicted from sediment properties.

Keywords: sediments; grain size; phosphorus forms; major elements; coastal areas 


\section{INTRODUCTION}

The phosphorus cycle has a multiple compound sedimentary phase (Emsley, 1980) since phosphate can occur in the sediment in the form of calcium, iron or aluminum precipitates or can be adsorbed onto the surface of minerals. Phosphorus is also present in various organic forms (living or dead). Nürnberg and Peters (1984) have pointed out that some sedimentary phosphorus can be released at certain periods of the year and sometimes contributes to lake water eutrophication. Although phosphorus limitation is well known in freshwater, this nutrient may also be important in transient zones such as estuaries and coastal environments (Harrisson et al., 1990 ; Bauerfeind et al., 1990). The importance of sediments as a potential source of phosphorus has also been highlighted in shallow coastal areas (Fisher et al., 1982). Exchangeable phosphate can escape to overlying water when fine particles are put back into suspension by bottom currents and Fe(III)-bound phosphate can dissolve under reduced conditions. Therefore, to better understand sedimentary phosphorus pools, sedimentary phosphorus speciation must be studied. The most promising method is the wet sequential chemical extraction technique (Ruttenberg, 1990, 1992). In addition, relationships between phosphorus forms and minerals or major chemical elements in sediments can be used to infer the identity of sedimentary P. Such studies have mainly been carried out in lakes. Williams (1976) found correlations between sediment characteristics and phosphorus species in 48 surficial sediments from Lake Erie. Ostrofsky (1987) also found significant correlations between iron and inorganic phosphorus species and between organic matter and organic phosphorus in surficial sediments collected from 66 lakes in North Eastern America. According to these authors, this information could serve as the basis for empirical models, enabling limnologists to predict phosphorus species in sediments and, ultimately, predict potential rates of internal phosphorus loading. But hardly any information is available about 
relationships between phosphorus forms and sediment characterization in the marine environment (Morse and Cook, 1978 ; Slomp et al., 1996).

The purpose of this paper is to examine the factors influencing the distribution of phosphorus forms in coastal and estuarine sediments, giving particular attention to major elements and particle size. Additionally, the question of whether measurement of easily accessible sediment variables may help to predict $\mathrm{P}$ behavior in the absence of speciation data is raised. Our study was carried out in three areas exhibiting a wide range of sediment characteristics.

\section{MATERIALS AND METHODS}

\subsection{Surveyed areas and sediment characteristics}

Three areas with various types of sediments were studied : the Bay of Seine located on the northern coast of France (English Channel), the Loire estuary and the Gironde estuary located on France’s Atlantic coast (figure 1).

The Bay of Seine has been described previously (Aminot et al., 1993 ; Andrieux and Aminot, 1997). Fine to very fine sands (lutites < 5 \%) were found by Avoine (1986) close to the Seine estuary mouth (international classification of sediments according to Wentworth, 1922 and Larsonneur, 1971). However, lutites can locally reach 10-20 \% and exceptionally up to $75 \%$ southward from the estuary's mouth. In the central and western bay, sediments are mainly gravel and gravelly coarse sand. Sediments have a terrigeneous siliceous fraction and a marine carbonate fraction, decreasing from west (50-70 \%) to east $(<40 \%)$ along with an enrichment in fine particles.

A full description of the Loire estuary has been given by Meybeck et al. (1988). The present study only took place in the outer estuary (figure 1). According to the CSEEL (1984), mud is found in the north channel and muddy-sand to sandy-mud in the other areas of the 
outer estuary. The fine fraction $(<40 \mu \mathrm{m})$ is composed of silts (35\%), carbonates $(17 \%)$, clay minerals and some organic matter (Migniot and Le Hir , 1996).

The Gironde (figure 1) is formed by the junction of the Garonne and Dordogne rivers. Detailed description of the estuary has been given by Castaing (1981). The estuarine sediments consist of silt and clay in the channels, where samples were collected. According to Jouanneau and Latouche (1981), most of these sediments are characterized by a predominance of the small fraction, notably silts $(<2 \mu \mathrm{m}: 35 \% ; 2-60 \mu \mathrm{m}: 56 \%$; $>60 \mu \mathrm{m}$ : $9 \%$ ). Sediments are mainly composed of carbonates (5 to $10 \%$ ), quartz and feldspars (20 to $40 \%$ ) and clays, etc. (30 to $60 \%)$.

\subsection{Sampling}

In the Bay of Seine, sediments were collected in fifteen sampling stations during four cruises in 1992 and three in 1994 (Andrieux and Aminot, 1997). Sampling stations were selected for fair representation of the various types of sediments in the Bay of Seine.

In the Loire and Gironde estuaries, five and seven stations were sampled, respectively, in February 1991.

The sediment was sampled using a Shipek grab. Sub-samples of the sediments' superficial oxic layer (about $2 \mathrm{~cm}$ )were put in polycarbonate flasks and stored frozen $(-20$ ${ }^{\circ} \mathrm{C}$ ). Based on a sediment grain-size study, only the $<500 \mu \mathrm{m}$ fraction was analyzed, thus ensuring that sediments were both homogeneous and representative (Andrieux and Aminot, 1997). Around $100 \mathrm{~g}$ and $50 \mathrm{~g}$, respectively, of dry sediments were available from the Bay of Seine and the other sites for analysis. However the available amount of sediment did not enable all the parameters in every sediment or every grain size class to be determined. Grain size studies were performed after dry sieving into classes according to Wentworth (1922). Dry sieving was preferred to wet sieving in order to prevent leaching of exchangeable phosphate by the sieving water. 


\subsection{Sequential extraction of phosphorus pools and analysis}

The samples were freeze-dried before analysis. This method is not recommended by Golterman (1996). However, the effects of drying and freeze-drying on the various forms of P have been tested by De Lange (1992), using some representative samples of sediments. No significant deviations were found between results obtained on these processed sediments and those obtained on the identical but unprocessed « wet » samples. In addition, an evaluation of exchangeable phosphate, the most labile form of sedimentary phosphorus, performed on fresh, frozen and freeze-dried sediments has shown that the exchangeable phosphate results were not significantly changed by freezing or freeze-drying (Andrieux-Loyer, 1997).

A detailed analysis of sedimentary phosphorus can be found in Andrieux and Aminot (1997). The main features are:

Total sedimentary phosphorus (TP) was measured following Rao and Reddi’s (1990) technique after ashing at $500{ }^{\circ} \mathrm{C}$. The major reservoirs of sedimentary $\mathrm{P}$ were determined using the widespread sequential method of Williams et al. (1976), as modified by Psenner et al. (1988) : (1) the non-apatite inorganic phosphate (NAIP) fraction which actually represents Fe- and Al-bound P (Fe/Al-P) and loosely sorbed, so-called exchangeable phosphate (exchP); (2) the calcium-bound phosphate (Ca-P) fraction; (3) the organic phosphorus fraction (orga-P) calculated by difference (TP minus NAIP and Ca-P). The extraction scheme used in this study was recommended in a workshop on phosphorus in sediments (Jensen and Thamdrup, 1993) and by Petterson et al . (1988).

In addition, exch-P, which is very labile in oxic conditions, was determined using the infinite dilution extrapolation method (Aminot and Andrieux, 1996).

Sequential extraction was applied to the entire amount of sediment and, when sufficient amounts of sediment were available, also on the grain-size classes. All classes could be 
analyzed for the Bay of Seine but only the fine fraction $(<63 \mu \mathrm{m})$ was analyzed for the Loire and Gironde estuaries.

Analysis of sediments for major elements was performed by the Centre de Recherches Pétrographique et Chimique (CRPG/CNRS). The sample was dissolved by a fusion with $\mathrm{LiBO}_{2}$ and $\mathrm{HNO}_{3}$, and the major elements were then measured by ICP-emission.

\section{RESULTS AND DISCUSSION}

\subsection{Sediment characteristics}

The sediment characteristics determined from the collected samples are given in table 1. In the Bay of Seine, data from previous work (Andrieux and Aminot, 1997) can be summarized as follows. Since lutites $(<63 \mu \mathrm{m})$ never exceeded $5 \%$ and grain size fractions between 125 and $500 \mu \mathrm{m}$ were predominant (table 1), sediments from the Bay of Seine were all fine sands or welding sands. The finest sediments were always found towards the Seine's mouth (stations S14, S15, S16 and S17).

In the Loire estuary, sediments presented a wide range characteristics (table 1), from mud to coarse sand. At stations L21 and L24 upstream, sediments were characterized by a dominant lutite fraction (over $74 \%$ of total sediment). At the estuary's mouth, three types of sediments were observed: at station L19 and L20, sediments were respectively coarse and fine sands, with lutites making up less than $2 \%$. At station L16, the sediment was typical mud (93 $\%$ of lutites).

In the Gironde, all sediments remained within the category of mud (lutites $>5 \%$; table 1). In the channel on the left, sediments at stations G8, G9 and G11 were typical muds (> 75 $\%$ of lutites), while at station G7 and G10 they were sandy muds. In the channel on the right (stations G12 and G13), sediments were muddy sands (lutites < $12 \%$ ). 
A Principal Component Analysis showed that major elements were not correlated with grain-size fractions 63-500 $\mu \mathrm{m}$, except in the Bay of Seine where significant correlations were observed with the 63-125 $\mu \mathrm{m}$ fraction. Therefore, iron and aluminum mainly appear to be present in the fine fraction $(<63 \mu \mathrm{m})$.

\subsection{Summary of phosphorus speciation}

The phosphorus forms found in the three surveyed areas are summarized in table 2. Furthermore, phosphorus speciation in the Bay of Seine has been fully described by Andrieux and Aminot (1997).

Total $\mathrm{P}$ concentration ranges were close in the Bay of Seine $\left(6-22 \mu \mathrm{mol} \mathrm{g} \mathrm{g}^{-1}\right)$ and in the Gironde (4-25 $\mu \mathrm{mol} \mathrm{g}{ }^{-1}$ ), but concentrations were higher in the Loire estuary (17-44 $\mu \mathrm{mol} \mathrm{g}$ $1)$.

Calcium-bound phosphate (Ca-P) in the Bay of Seine showed little variation, both over the whole area and over time (Andrieux and Aminot, 1997). In the Loire estuary (February 1991) concentrations in the areas studied were also very similar. Nevertheless, they were higher than in the Bay of Seine (an average of $9 \mu \mathrm{mol} \mathrm{g}^{-1}$ compared to $6 \mu \mathrm{mol} \mathrm{g} \mathrm{g}^{-1}$ ). In the Gironde estuary, concentrations ranged from $1.9 \mu \mathrm{mol} \mathrm{g}^{-1}$ in the right channel to $7.8 \mu \mathrm{mol} \mathrm{g}{ }^{-1}$ in the left channel. Ca-P, in the Bay of Seine, was invariably the dominant form of phosphorus, with most values exceeding $50 \%$ of the total phosphorus pool.

Fe/Al-P concentrations in the Bay of Seine showed a east/west gradient which highlighted the influence of particulate inputs from the Seine plume (Andrieux and Aminot, 1997). Concentration ranges were close in the Bay of Seine and in the Gironde (respectively 0.06-5.6 and 0.63-5.5 $\mu \mathrm{mol} \mathrm{g}{ }^{-1}$ ), while concentrations were slightly higher in the Loire estuary (1.7-7.3 $\mu \mathrm{mol} \mathrm{g}^{-1}$ ). The highest concentrations of Fe/Al-P were observed at the mouth of the Seine estuary, at upstream stations in the Loire and in the left channel of the Gironde. Fe/AlP proportions related to TP remained roughly between 10 to $20 \%$ in any given site. 
Exch-P concentration ranges were very similar in the Bay of Seine and in the Gironde (about 0.1-2.7 $\mu \mathrm{mol} \mathrm{g} \mathrm{g}^{-1}$ ). In the center and western Bay of Seine, at the Loire estuary's mouth and in the right channel of the Gironde, exch-P concentrations never exceeded $1 \mu \mathrm{mol} \mathrm{g}^{-1}$, i.e less than $10 \%$ of the total phosphorus pool. The highest concentrations were observed at the Seine estuary's mouth (Andrieux and Aminot, 1997), in the left channel of the Gironde and at upstream stations of the Loire estuary with an absolute maximum of $6.5 \mu \mathrm{mol} \mathrm{g} \mathrm{g}^{-1}$. Nevertheless, exch-P rarely exceeded $15 \%$ of total phosphorus.

\subsection{Sediment characteristics and $P$ forms}

Relationships were examined by simple linear regression using Statgraphics software. The significant regression is presented in table 3.

\section{Grain size}

Significant correlations with certain size fractions could be found for Fe/Al-P, exch-P and Ca-P, depending on the area. Table 3 shows that exch-P and Fe/Al-P were significantly correlated with the fine fraction $(<63 \mu \mathrm{m})$ in the three areas but also with the other fractions in the Bay of Seine. These results are in agreement with those of Rao and Berner (1997) who also found a good relationship between Fe/Al-P and the fine fraction $(<20 \mu \mathrm{m})$ for sediments collected near the mouth of the Chang Jiang (Yangtze River, China). However, Ca-P was not correlated with grain size characteristics, except with the fine fraction in the Gironde and with the coarsest fraction $(250-500 \mu \mathrm{m})$ in the Bay of Seine.

The Fe/Al-P and exch-P values have been extrapolated from regression lines to $100 \%$ of fine fraction $(<63 \mu \mathrm{m})$, in order to compare them with direct measurements taken in the sieved fraction itself (table 4).

Dry sieving may be responsible for the incomplete separation of the finest particles. They would thus contribute to (and therefore "contaminate ») P-forms in other classes. However, data from wet sieving of sediments from other cruises in the Bay of Seine did not 
indicate any significant and/or systematic underestimation of the finest fraction. Therefore, the results of $\mathrm{P}$ speciation in size classes above $63 \mu \mathrm{m}$ are considered to be valid.

The higher concentration of NAIP (Fe/Al-P + exch-P) in the fine fraction compared to the other fractions was clearly shown in the Bay of Seine sediments (figure 2). Near the estuary's mouth, the NAIP concentration in the fine fraction was about twice the mean concentration in the other classes. In offshore sediments (station S7) a ten-fold factor was observed.

Exch-P, one of the NAIP components, also exhibited higher concentrations in the finest fraction than in the others, but, unlike NAIP, its concentration decreased progressively as a function of increasing grain size. This typical exch-P behavior highlights the importance of surface processes. The Fe concentration was significantly correlated with the proportion of fine particles, but not with the other size classes (table 3). This shows the particular nature of the fine fraction and fits the hypothesis of phosphate chemisorption on colloidal ferric (hydroxo-) oxides adsorbed at the surface of the fine particles (Carroll, 1958 ; Aller et al., 1986 ; Parfitt, 1989 ; Slomp et al., 1998).

Fe/Al-P, the second component of NAIP (represented by the difference between the first two bars for each size class in figure 2) was often more concentrated in the fine particles, but there are some exceptions. At stations S15 and S16, near the estuary's mouth (see figure 1), Fe/Al-P was almost equally distributed throughout the various size classes, despite an unexplained drop in concentration in the 63-125 $\mu \mathrm{m}$ class at station S16. Fe/Al-P's behavior, totally distinct from that of exch-P, proves that the extraction procedure actually identifies two different types of Fe-associated phosphate.

The Fe/Al-P and exch-P values extrapolated from the regression lines to $100 \%$ of the fine fraction compare well with extraction measurements in the Loire and Gironde estuaries, while in the Bay of Seine, they were 10 to 40 times higher than the extraction values. This has 
been attributed to the fact that exch-P and Fe/Al-P were also distributed in the other grain size classes (table 3 shows correlations of exch-P and Fe/Al-P compared to higher grain size classes). This was not the case in the Loire and Gironde estuaries where high proportions of the fine fraction were found.

The distribution pattern of Ca-P over the size classes (Bay of Seine) was more variable, with no marked feature. The two classes under $125 \mu$ m were almost invariably among the three classes with the highest Ca-P concentrations. One other class of large size particles often exhibited high concentrations (either $250-500 \mu \mathrm{m}$ or 500-1000 $\mu \mathrm{m}$, assumed to contain most shell debris). This «smooth » distribution throughout the size classes suggests that surface effects are of minor importance and that calcium phosphate is mainly present within the matrix of the sediment minerals.

As for the organic fraction, it is often stated that it is mainly associated with the fine particles of sediments. A relationship between orga-C and the fraction $<50 \mu \mathrm{m}$ (range: $0-80$ \%) was found by Boust (1981) for the sediments of the Seine estuary and the eastern Bay of Seine. Therefore, we examined the relationship between orga-P and the $<63 \mu \mathrm{m}$ fraction (figure 3). A correlation was observed in the Loire and Gironde estuaries but not in the Bay of Seine. However, in the Bay of Seine and in the Loire estuary mouth, the sediments studied were more sandy, with low fine particle proportions (fraction $<63 \mu$ m less than $5 \%$ ). Nevertheless, in the latter areas concentrations of orga-P still reach 5-8 $\mu$ mol g ${ }^{-1}$. These concentrations are comparable to those found in the Gironde estuary in sediments with $\sim 50$ \% fine fraction. This shows that, in such sandy sediments, organic matter is also associated with larger particles (adsorbed or in the form of bacterial film).

\section{Calcium}

In the Bay of Seine, Ca-P concentrations were not related to sedimentary Ca concentrations, while a positive relationship could be found in both the Loire and Gironde 
sites (figure 4). Good relationships were also observed between Ca percentage and the fine fraction (figure 3). This suggests that Ca-P was predominantly of metamorphic, continental origin in the Loire and Gironde estuaries. From the slope of the relationships observed in these estuaries, the $\mathrm{Ca} / \mathrm{P}$ molar ratio was about 80 . Unfortunately, no data has been found in literature for comparison purposes. In contrast, the absence of correlation between Ca-P and Ca concentrations in the Bay of Seine, suggests that Ca-P is mainly from marine origin. Indeed, according to Stumm (1992), apatite can be formed not only during calcium carbonate precipitation but also at the surface of shell fragments. Our results in the Bay of Seine are in agreement with those of Morse and Cook (1978), who did not find any relationship between $\mathrm{CaCO}_{3}$ and Ca-P concentrations in North Atlantic deep-sea and continental slope sediments. One of the questions often raised about Ca-P forms is whether they constitute a stable pool or can be mobilized (Golterman, 1988 ; Gomez et al. 1999 ; Moutin et al., 1993 ). After reassessing the phase diagram of calcium and iron bound phosphate in fresh water conditions, Golterman (1988) came to the conclusion that an exchange between both phases may occur in the range of $\mathrm{pH}$ and phosphate concentration of most natural systems without substantial release of phosphate into water. In an attempt to apply his approach to seawater systems, we noted that the lower orthophosphate equilibrium constants, together with the high calcium concentration, generate a drastic shift in equilibrium curves toward low phosphate concentrations, by 3 to 5 orders of magnitude. Hence, the usual domain of $\mathrm{pH}$ and phosphate concentrations in marine waters and sediments was entirely within the range of precipitated hydroxyapatite (and fluoroapatite). Consequently, for marine systems, this supports two points: firstly, that apatites actually constitute an insoluble reservoir of phosphorus, secondly, that soluble phosphate concentrations are far from the equilibrium concentration, which suggests that apatite formation kinetics are very slow and do not control phosphate 
concentrations in water. This highlights the fact that data from fresh water systems do not apply to marine water systems.

The relationships between sedimentary $\mathrm{Ca}$ and Ca-P were therefore considered to be mostly influenced by the source of calcium-bound phosphate rather than by early sedimentary processes.

\section{Iron and aluminum}

Aluminum and iron were systematically correlated, and aluminum-bound phosphate concentrations represented only 5-20 \% of iron-bound phosphate concentrations, which is close to the method's precision. Consequently only relationships with iron were studied.

Linear correlations of Fe/Al-P and exch-P versus Fe have been used as a tool to analyze Fe-P relationships in sediments. A significant $\mathrm{X}$-axis $(\mathrm{Fe})$ intercept has been understood to indicate the presence of an iron-rich mineral phase with a low occluded phosphate concentration or a low phosphate surface interaction. The regression slope can therefore be assumed to specifically reflect a characteristic of the matrix components that exhibit an actual Fe-P interaction.

A significant X-axis intercept was found for the Bay of Seine both with Fe/Al-P and exch-P versus Fe. As shown in figure 4, this mainly concerned the coarser marine sediments located far from the estuary's mouth. An intercept was also observed for the Loire estuary and, to a lesser extent, for the Gironde estuary, but only for exch-P. This means that some Fecontaining matrices have a rather lower adsorption capacity than in the Bay of Seine.

By and large, a positive, significant correlation was found between iron and Fe/Al-P (figure 4). Morse and Cook (1978) and Jensen and Thamdrup (1993) have also shown that NAIP (Fe/Al-P plus exch-P) was closely correlated with Fe. Molar Fe:P ratios $( \pm 1$ standard error) were respectively $30 \pm 2.5,110 \pm 40$ and $140 \pm 20$, in the Bay of Seine, the Loire and 
Gironde estuaries. The Fe/P ratio found in the Bay of Seine is close to the values reported for superficial sediments in the Wadden Sea (12-15 ; Salomon and Gerritse, 1981) or in Lake Erie (30 ; Williams et al., 1976). It has been established that most of the iron in marine sediments is non-reactive and bound in silicates where it can not interact with P (Raiswell et al., 1998). Therefore, the differences in the correlation of Fe-P and Fe may have been affected by the size of the reactive Fe pool. In order to check this, the amount of Fe extracted together with the NAIP fraction was measured in a few sediments available from the Bay of Seine (stations S15 and S16) and the Gironde (stations G8, G9 and G10). The results show that the proportion of reactive $\mathrm{Fe}(\mathrm{rFe})$ was almost constant and similar in both areas (15-17 \%) of total $\mathrm{Fe}$ ), corresponding to $\mathrm{rFe} / \mathrm{P}$ ratios of about 6 in the Bay of Seine and 22 in the Gironde. These figures may be compared with values (about 14) found by Moutin et al. (1993) in the surface layer of sediments from Mediterranean lagoons. Our data confirm the higher $\mathrm{Fe} / \mathrm{P}$ ratios obtained in the Loire and Gironde, which means that the sediment traps less phosphate than the amount expected from the reactive Fe. Salomon and Gerritse (1981) observed a significant increase of the $\mathrm{Fe} / \mathrm{P}$ ratio in the anoxic subsurface layer of the sediments in the Wadden Sea (30, versus 15 in the oxic layer). According to Stumm (1992), the reductiondissolution of Fe-oxides at the surface of minerals and clays proceeds in several steps. The last one, i.e., detachment of Fe II ions from the matrix, is slow. When Fe-oxides-PO4 complexes are destroyed, PO4 is solubilized while Fe II remains attached to the solid for some time. In addition to the fact that within the matrix, Fe is unaffected by surface processes, this may explain an increase of the Fe/P ratio of solids in water or sediment bodies exhibiting temporary anoxia or hypoxia. As the large macrotidal, turbid estuaries (Loire and Gironde) exhibit frequent hypoxia (Romana and Thouvenin, 1990), their high Fe/P ratio may support the hypothesis that slow detachment of Fe II ions from the solid matrix is the rate-determining process. 
A significant relationship was observed between exch-P and Fe (table 3 and figure 4) and between exch-P and Fe/Al-P (Andrieux and Aminot, 1997). These correlations are attributed to the adsorption of phosphate on iron oxides, hydroxides (called Fe oxides) and clays, an important process in marine and freshwater sediments (Lijklema, 1977, 1980 ; Jensen et Thamdrup, 1993 ; Slomp et al., 1996). For exch-P, molar Fe:P ratios are $100 \pm 20$, $70 \pm 30,200 \pm 20$, in the Bay of Seine, the Loire estuary and the Gironde respectively. These differences between the molar Fe:P ratio in the three sites may be attributed to different clay mineral properties, although the range is narrower than for Fe/Al-P. According to Ruttenberg (1992) and Slomp et al. (1996 b), Fe detrital crystalline phases from wind or rivers should have a lower potential P sorption (high Fe:P ratio) than the « amorphous » Fe oxides (with a large surface area) formed in situ in marine sediments. The available data do not enable us to confirm this assertion, since the ratio in the Loire estuary is lower than that of the more marine site of the Bay of Seine. According to theoretical studies by Golterman (1995) and experimental data from Lijklema (1980), each adsorb P inactivates $2 \mathrm{Fe}(\mathrm{OOH})$. Using these values, it is easy to calculate the proportion of Fe linked to exch-P related to the reactive Fe extracted with the NAIP fraction and determined as above. These proportions were respectively about 12, 18 and $6 \%$, in the Bay of Seine, the Loire and Gironde estuaries. This shows that only a low proportion of reactive Fe is involved in $\mathrm{P}$ adsorption, as for Fe-P overall.

It is quite difficult to compare our molar Fe:P ratios (for exch-P) to data in literature, since most works either do not provide such ratios or do not discriminate between Fe/Al-P and exch-P.

\section{Organic Carbon}

Orga-P has been tentatively examined as a function of the organic-C content of the sediments using the few available organic-C data. Only a very weak correlation was observed 
in the orga-C poor ( $<0.6 \%)$ marine sediments of the Bay of Seine. In the Gironde estuary (orga-C : 0.1-1.3\%), a slightly better relationship was found : orga-P $=0.0085$ orga-C + 0.003, $\mathrm{r}^{2}=0.84, \mathrm{n}=6$, where $\mathrm{P}$ and $\mathrm{C}$ are in $\mu \mathrm{mol} \mathrm{g}^{-1}$. Surprisingly, the slope $(\mathrm{C} / \mathrm{P}=118)$ is close to the Redfield ratio of 106 for marine plankton (Redfield et al., 1963). These C/P values are close to those found by Eijsink et al. (1997) for oxic sediments in the eastern Mediterranean (average $\approx 86$ ). No orga-C data were available for the Loire estuary. Morse and Cook (1978) found a relationship between orga-C and orga-P in sediments of the NorthAtlantic continental slope, with a C/P molar ratio of 124 . On the contrary, other authors (Froelich, 1982 ; de Lange, 1992) mentioned that no correlation could be established in organic-element poor sediments.

It is assumed that the lack of correlation in such sediments is mostly attributable to the difficulty of measuring low orga-P concentrations by difference (de Lange, 1992).

\section{CONCLUSION}

The objective of this work was to improve knowledge of phosphorus species distribution in marine sediments by providing additional information on general characteristics of the sediment, like grain size and major elements. It has been shown that the exchangeable and $\mathrm{Fe} / \mathrm{Al}$ phosphate were preferentially associated with the fine particles $(<63$ $\mu \mathrm{m})$ in the three studied areas, but that, in the more sandy sediments of the Bay of Seine, these forms were also found in significant concentrations in the larger size classes. For that reason, an attempt to extrapolate concentrations of these P-forms from the linear regressions between them and the proportion of the fine fraction failed in the Bay of Seine, while it was successful in the two other areas which are characterized by high amounts of fine fraction. In spite of this, the relationship between Fe and exch-P and Fe/Al-P provided some information 
on the association of these forms with Fe ions at the surface or within the Fe-containing matrix.

Calcium-bound phosphate showed variable distributions over size classes and as a function of sedimentary calcium. A significant correlation with fine particles and calcium suggests a metamorphic origin of Ca-P (Gironde), while the absence of correlation suggests a marine origin (Bay of Seine).

As for organic phosphorus, some additional information is obtained by knowing the organic carbon content of sediments, when available.

As a corollary of this work, it is interesting to consider whether such data may allow us to infer some sediment properties in relation to phosphorus forms, without specifically measuring those forms.

In areas where specific relationships have previously been established, good estimates of P-forms can be predicted from sediment properties. Overall, for a location where no P data is available, grain size distributions and geochemical characteristics can give a rough idea of the P-forms which can be expected. However, owing to large differences between areas, getting precise information on P-forms will require a specific P-extraction study.

For the current knowledge of P-forms, there is no satisfactory alternative to measuring them using classic chemical extraction techniques.

\section{ACKNOWLEDGEMENTS}

This work was funded by the research program PNOC (Programme National d’Océanographie Côtière). We thank our laboratory colleagues for their collaboration in sampling and data acquisition in the Bay of Seine and our colleagues working for the national 
monitoring network (Réseau National d'Observation) for their help during cruises in the Loire and Gironde estuaries.

\section{REFERENCES}

Aller, R. C., Mackin, J. E. \& Cox, R. T. 1986 Diagenesis of Fe and S in Amazon inner shelf muds : apparent dominance of Fe reduction and implications for the genesis of ironstones. Continental Shelf Research 6, 263-289.

Aminot, A., Guillaud, J. F. \& Andrieux, F. 1993 Speciation du phosphore et apports en Baie de Seine orientale. Oceanologica Act 16(5-6), 617-623.

Aminot, A. \& Andrieux, F. 1996 Concept and determination of exchangeable phosphate in aquatic sediments. Water Research 30(11), 2805-2811.

Andrieux, F. \& Aminot, A. 1997 A two-year survey of phosphorus speciation in the sediments of the Bay of Seine (France). Continental Shelf Research 17(10) , 1229-1245.

Andrieux-Loyer, F. 1997 Les formes de phosphore particulaire et sédimentaire en environnement côtier. Méthodes d'analyse, biodisponibilité, échange. Thesis, Université de Bretagne Occidentale, Brest 312 pp.

Avoine, J. 1986 Sediment exchanges between the Seine estuary and its adjacent shelf. Journal of Geology Society 144, 135-148.

Bauerfeind, E., Hickel, W., Niermann, U. \& Westernhagen, H.V. 1990 Phytoplankton biomass and potential nutrient limitation of phytoplancton development in the southeastern North Sea in spring 1985 and 1986. Netherlands Journal of Sea Research 25(1-2), 131-142.

Boust, D. 1981 Les métaux-traces dans l'estuaire de la Seine et ses abords. Thesis of Geology, Université de Caen, France, 186 pp.

Carroll, D. 1958 The role of clay minerals in the transportation of iron. Geochimica Cosmochimica Acta 14, 1-27. 
Castaing, P. 1981 Le transfert à l'océan des suspensions estuariennes. Cas de la Gironde. Mémoire de l'Institut de Géologie du Bassin d'Aquitaine. Thèse Doct. Etat ès-Sc., Université de Bordeaux I, 530 pp.

C.S.E.E.L. 1984 Rapport scientifique et technique final du C.S.E.E.L., Comité Scientifique pour l'Environnement de l'Estuaire de la Loire, nº 55, 158 pp.

De Lange, G.J. 1992 Distribution of various extracted phosphorus compounds in the interbedded turbiditic/pelagic sediments of the Madeira Abyssal Plain, eastern North Atlantic. Marine Geology 109, 115-139.

Eijsink, L.M., Krom, M.D. \& de Lange, G.J. 1997 The use of sequential extraction techniques for sedimentary phosphorus in eastern Mediterranean sediments. Marine Geology 139, $147-155$.

Emsley, J. 1980 The phosphorus cycle. The Handbook of environmental chemistry, Springer-Verlag, Berlin, 1(part A), 147-167.

Fisher, T. R., Carlson, P. R. \& Barber, R. T. 1982 Sediment nutrient regeneration in three North Carolina estuaries. Estuarine Coastal and Shelf Science 14, 101-116.

Froelich, P.N., Bender, M.L., Luedtke, N.A., Heath, G.R. \& Devries, T. 1982. The marine phosphorus cycle. American Journal of Science 282, 474-511.

Golterman, H. L . 1988 The calcium- and iron bound phosphate phase diagram. Hydrobiologia 159, 149-151.

Golterman, H. L. 1995 Theoretical aspects of the adsorption of ortho-phosphate onto iron-hydroxide. Hydrobiologia 315, 59-68.

Golterman, H. L. 1996 Fractionation of sediment phosphate with chelating compounds : a simplification, and comparison with other methods. Hydrobiologia 335, 87-95.

Gomez, E., Durillon, C., Rofes, G. \& Picot, B . 1999 Phosphate adsorption and release from sediments of brackish lagoons : $\mathrm{pH}, \mathrm{O}_{2}$ and loading influence. Water Research 33(10), 2437-2447.

Harrison, P. J., Hu, M.H., Yang, Y.P. \& Lu, X. 1990 Phosphate limitation in estuarine and coastal waters of China. Journal of Experimental Marine Biology and Ecology 140, 7987. 
Jensen, H.S. \& Thamdrup, Bo 1993 Iron-bound phosphorus in marine sediments as measured by bicarbonate-dithionite extraction. Hydrobiologia 253, 47-59.

Jouanneau, J. M. \& Latouche, C. 1981 The Gironde Estuary. Contribution to sedimentology. Füchtbauer, H., (Ed.). E. Schweizerbart'sche Verlagsbuchhandlung (Nägele u. Obermiller), Stuttgart, 1981, 115 p.

Larsonneur, C. 1971 Manche Centrale et Baie de Seine: géologie du substratum et des dépôts meubles. Thèse Doct. Etat ès-Sci., Université de Caen, 394 pp.

Lijklema, L. 1977 The role of iron in the exchange of phosphate between water and sediments. H. L. Golterman (ed.), Interactions between sediments and freshwater : pp 313-317. Dr W. Junk B. V., The Hague.

Lijklema, L. 1980 Interaction of orthophosphate with iron (III) and aluminium hydroxides.

Environmental Science and Technology 14(5), 537-541.

Meybeck, M., Cauwet, G., Dessery, S., Somville, M., Gouleau, D. \& Billen, G. 1988 Nutrients (Organic C, P, N, Si) in the Eutophic River Loire (France) and its estuary. Estuarine Coastal and Shelf Science 27, 595-624.

Migniot, C. \& Le Hir, P. 1996 Estuaire de la Loire. Rapports de synthèse de l'APEEL (1984-1994). Ed. APEEL. I. Hydrosédimentaire, 82 pp.

Morse, J. W. \& Cook, N. 1978 The distribution and forms of phosphorus in North Atlantic Ocean deep-sea and continental slope sediments. Limnology and Oceanography 23(4), 825-830.

Moutin, T., Picot, B., Ximenes, M.C. \& Bontoux, J. 1993 Seasonal variations of P compounds and their concentrations in two coastal lagoons (Herault, France). Hydrobiologia 252, 45-59.

Nürnberg, G. \& Peters, R.H. 1984 The importance of internal phosphorus load to the eutrophication of lakes with anoxic hypolimnia. Verhandlungen Internationale Vereinigung für Limnologie 22, 190-194.

Ostrofsky, M. L. 1987 Phosphorus species in the surficial sediments of lakes of Eastern North America. Canadian Journal of Fisheries and Aquatic Sciences 44, 960-966. 
Parfitt, R. L. 1989 Phosphate reactions with natural allophane, ferrihydrite and goethite. Journal of Soil Science 40, 359-369.

Pettersson, K., Boström, B. \& Jacobsen, O-S. 1988 Phosphorus in sediments-speciation and analysis. Hydrobiologia 170, 91-101.

Psenner, R., Boström, B., Dinka, M., Petterson, K., Pucsko, R. \& Sager, M. 1988 Fractionation of phosphorus in suspended matter and sediment. Archiv für Hydrobiologie Beiheft Ergebnis Limnologie 30, 98-103.

Raiswell, R. \& Canfield, D.E. 1998 Sources of iron for pyrite formation in marine sediments. American Journal of Science 298, 219-245.

Rao, C. R. M. \& Reddi, G. S. 1990 Decomposition procedure with aqua regia and hydrofluoric acid at room temperature for the spectrophotometric determination of phosphorus in rocks and minerals. Analytica Chimica Acta 237, 251-252.

Rao, Ji-L. \& Berner, R. A. 1997 Time variations of phosphorus and sources of sediments beneath the Chang Jiang (Yangtze River). Marine Geology 139, 95-108.

Redfield, A.C., Ketchum, B.H. \& Richards, F.A. 1963 The influence of organisms on the composition of seawater. In : M.N. Hill (Editor), The Sea. Wiley-Interscience, New-York, 2, pp. 26-77.

Romana, L.A. \& Thouvenin, B. 1990 Influence du bouchon vaseux sur les variations des concentrations en oxygène dissous : cas de l'estuaire de la Loire. La Houille Blanche 3/4, 257-262.

Ruttenberg, K. C. 1990 Diagenesis and burial of phosphorus in marine sediments: Implications for the marine phosphorus budget. Ph. D. thesis, Yale Univ., 375 pp.

Ruttenberg, K. C. 1992 Development of a sequential extraction method for different forms of phosphorus in marine sediments. Limnology and Oceanography 37(7), 1460-1482.

Salomons, W. \& Gerritse, R. G. 1981 Some observations on the occurrence of phosphorus in recent sediments from Western Europe. Science of the Total Environment 17, 37-49.

Slomp, C. P., Van der Gaast, S. J. \& Van Raaphorst, W. 1996 Phosphorus binding by poorly crystalline iron oxides in North Sea sediments. Marine Chemistry 52, 55-73. 
Slomp, C.P., Malschaert, J.F.P. \& Van Raaphorst, W. 1998 The role of adsorption in sediment-water exchange of phosphate in North Sea continental margin sediments. Limnology and Oceanography 43(5), 832-846.

Stumm, W. 1992 Chemistry of the Solid-Water Interface. Processes at the mineralwater and particle-water interface in natural systems. A Wiley-Interscience Publication, NewYork, 428 pp.

Wenthworth, C. K. 1922 Grade and class terms for clastic sediments. Journal of Geology 30, 327-392.

Williams, J. D. H., Jaquet, J.-M. \& Thomas, R. L. 1976 Forms of phosphorus in the surficial sediments of lake Erie. Journal of the Fisheries Research Board of Canadia 33, 413429. 
Table 1. Grain size characteristics, major element and Organic C (Org. C) concentrations in the Bay of Seine, the Gironde and the Loire estuaries.

\begin{tabular}{|c|c|c|c|c|c|c|c|c|c|c|c|}
\hline Surveyed area & Station & Type of & $<63 \mu \mathrm{m}$ & $63 \mu \mathrm{m}-$ & $125^{(1)} \mu \mathrm{m}-$ & $>500 \mu \mathrm{m}$ & $\mathrm{SiO}_{2}$ & $\mathbf{A l}_{2} \mathbf{O}_{3}$ & $\mathrm{Fe}_{2} \mathrm{O}_{3}$ & $\mathrm{CaO}$ & Org. C \\
\hline & & sediment & & $125^{(1)} \mu \mathrm{m}$ & $500 \mu \mathrm{m}$ & & & $\%$ & & & $\%$ \\
\hline \multirow[t]{5}{*}{ Loire estuary } & L19 & Coarse sand & 1.2 & 0.4 & 18 & 80 & 78 & 9.4 & 1.6 & 1.4 & - \\
\hline & L20 & Fine sand & 1.9 & 3.8 & 79 & 15 & 72 & 9.4 & 1.9 & 4.1 & - \\
\hline & L21 & Mud & 75 & 23 & 1.1 & 0.8 & 47 & 11.5 & 4.6 & 6.8 & - \\
\hline & L24 & Mud & 74.7 & 11 & 9.3 & 4.6 & 49 & 11.7 & 4.7 & 5.1 & - \\
\hline & L26 & Mud & 93.4 & 2.3 & 1.6 & 2.7 & 43 & 13.3 & 5.5 & 5.6 & - \\
\hline \multirow[t]{7}{*}{ Gironde } & G7 & Sandy mud & 67 & 4 & 29 & 0.8 & 63 & 11 & 4 & 3.9 & 0.87 \\
\hline & G8 & Mud & 91 & 7 & 1.4 & 0.1 & 54 & 14 & 5.3 & 4.7 & 1.26 \\
\hline & G9 & Mud & 78 & 6.8 & 14 & 1.3 & 63 & 12 & 4.3 & 4.1 & 0.81 \\
\hline & G10 & Sandy mud & 39 & 2.1 & 57 & 1.7 & 71 & 10 & 3.4 & 3 & - \\
\hline & G11 & Mud & 84 & 14.3 & 1.4 & 0.1 & 64 & 11 & 3.9 & 5.3 & - \\
\hline & G12 & Fine sand & 11 & 0.7 & 57 & 31 & 87 & 6.2 & 1.2 & 0.7 & 0.11 \\
\hline & G13 & Coarse sand & 8.1 & 0.6 & 27 & 61 & 89 & 2.9 & 0.58 & 2.4 & 0.06 \\
\hline \multirow[t]{15}{*}{ Bay of Seine ${ }^{(2)}$} & S2 & Fine sand & 0.1 & 0.2 & 93 & 6.9 & 50 & 1.7 & 0.58 & 24 & 0.08 \\
\hline & S3 & Welding sand & 0.3 & 2.2 & 97 & 0.7 & 60 & 2 & 0.82 & 18 & 0.17 \\
\hline & $\mathrm{S} 4$ & Welding sand & 0.3 & 1.4 & 85 & 14 & 53 & 2 & 0.72 & 22 & 0.18 \\
\hline & S7 & Fine sand & 0.2 & 0.5 & 56 & 44 & 63 & 1 & 0.58 & 17 & 0.17 \\
\hline & S8 & Welding/fine sand & 0.31 & 1.4 & 71 & 28 & 58 & 2 & 0.71 & 19 & 0.16 \\
\hline & S9 & Fine sand & 0.8 & 1.4 & 42 & 56 & 46 & 2 & 0.92 & 25 & 0.28 \\
\hline & S10 & Welding/fine sand & 1.1 & 4.6 & 90 & 4 & 48 & 2 & 1.13 & 24 & 0.17 \\
\hline & S11 & Welding sand & 0.2 & 1.1 & 91 & 8 & 56 & 2 & 0.90 & 20 & 0.14 \\
\hline & S12 & Fine/welding sand & 0.3 & 1.8 & 60 & 38 & 54 & 2 & 0.58 & 21 & 0.18 \\
\hline & S13 & Fine/welding sand & 0.6 & 1.8 & 62 & 35 & 60 & 2 & 0.60 & 18 & 0.16 \\
\hline & S14 & Fine sand & 3.1 & 4.6 & 43 & 49 & 57 & 3 & 1.51 & 16 & 0.39 \\
\hline & S15 & Welding/fine sand & 1.4 & 2.3 & 87 & 10 & 72 & 2 & 1.17 & 11 & 0.36 \\
\hline & S16 & Welding sand & 1.4 & 4.5 & 89 & 5 & 64 & 3 & 1.14 & 15 & 0.34 \\
\hline & S17 & Welding sand & 2.3 & 6.8 & 86 & 5 & 67 & 3 & 1.06 & 13 & 0.15 \\
\hline & S18 & Welding sand & 0.61 & 3.2 & 80 & 16 & 54 & 2 & 0.94 & 21 & - \\
\hline
\end{tabular}

(1) For the sediments from the Loire estuary and the Gironde, separation at $160 \mu \mathrm{m}$ was used instead of $125 \mu \mathrm{m}$. This was shown to have little incidence on class proportions.

(2) For the Bay of Seine, data are averaged values over the four cruises of 1992 (Andrieux and Aminot, 1997).

- No sediment available 
Table 2. Concentrations of total phosphorus and phosphorus forms in the sediments of the Bay of Seine, the Loire estuary and the Gironde estuary.

Concentrations given in micromoles per gram of sediment.

\begin{tabular}{|c|c|c|c|c|c|c|}
\hline Surveyed area & Station & TP & Ca-P & Fe/Al-P & exch-P & orga-P \\
\hline \multirow[t]{5}{*}{ Loire estuary } & L19 & 19.2 & 9.8 & 1.8 & 0.18 & 7.4 \\
\hline & L20 & 16.8 & 7.4 & 1.7 & 0.25 & 7.5 \\
\hline & L21 & 41.5 & 9.7 & 6.1 & 6.5 & 19.2 \\
\hline & L24 & 42.7 & 6.3 & 7.2 & 5.7 & 23.4 \\
\hline & L26 & 44.4 & 9.8 & 4.5 & 6.4 & 23.7 \\
\hline \multirow[t]{7}{*}{ Gironde } & G7 & 21.1 & 6.2 & 2.6 & 2.2 & 10.0 \\
\hline & G8 & 25.4 & 7.6 & 5.5 & 2.7 & 9.5 \\
\hline & G9 & 21.1 & 7.8 & 4.1 & 2.4 & 6.7 \\
\hline & G10 & 18.3 & 6.8 & 3.3 & 1.3 & 6.8 \\
\hline & G11 & 23.9 & 7.7 & 3.5 & 2.3 & 10.4 \\
\hline & G12 & 8.3 & 3.6 & 1.5 & 0.35 & 2.8 \\
\hline & G13 & 4.2 & 1.9 & 0.63 & 0.15 & 1.6 \\
\hline \multirow[t]{15}{*}{ Bay of Seine $^{(1)}$} & S2 & 8.7 & 6.3 & 0.30 & 0.29 & 1.9 \\
\hline & S3 & 9.1 & 6.7 & 0.70 & 0.81 & 0.83 \\
\hline & S4 & 8.4 & 5.2 & 0.80 & 0.50 & 1.9 \\
\hline & S7 & 6.1 & 5.3 & 0.12 & 0.36 & 0.29 \\
\hline & S8 & 8.4 & 4.6 & 0.61 & 0.40 & 2.7 \\
\hline & S9 & 11.1 & 5.8 & 0.93 & 0.60 & 3.8 \\
\hline & $\mathrm{S} 10$ & 11.7 & 5.7 & 1.6 & 0.65 & 4.0 \\
\hline & $\mathrm{S} 11$ & 8.6 & 5.6 & 0.79 & 0.50 & 1.6 \\
\hline & $\mathrm{S} 12$ & 9.5 & 5.6 & 0.45 & 0.54 & 2.9 \\
\hline & $\mathrm{S} 13$ & 10.3 & 5.1 & 0.46 & 0.30 & 4.4 \\
\hline & S14 & 13.4 & 7.1 & 1.5 & 0.88 & 3.9 \\
\hline & S15 & 13.7 & 6.2 & 3.7 & 1.71 & 2.2 \\
\hline & S16 & 18.6 & 9.2 & 4.2 & 2.2 & 3.0 \\
\hline & S17 & 11.0 & 6.0 & 2.1 & 1.1 & 1.73 \\
\hline & S18 & 10.7 & 5.8 & 2.2 & 1.5 & 1.24 \\
\hline
\end{tabular}

(1) For the Bay of Seine, data are values averaged over the seven cruises undertaken in 1992 and 1994 (Andrieux and Aminot, 1997). 
Table 3. Significant (S : positive slope ; $\underline{S}$ : negative slope) linear regressions at the 95 percent confidence level. B: Bay of Seine ; L: Loire estuary ; G: Gironde estuary.

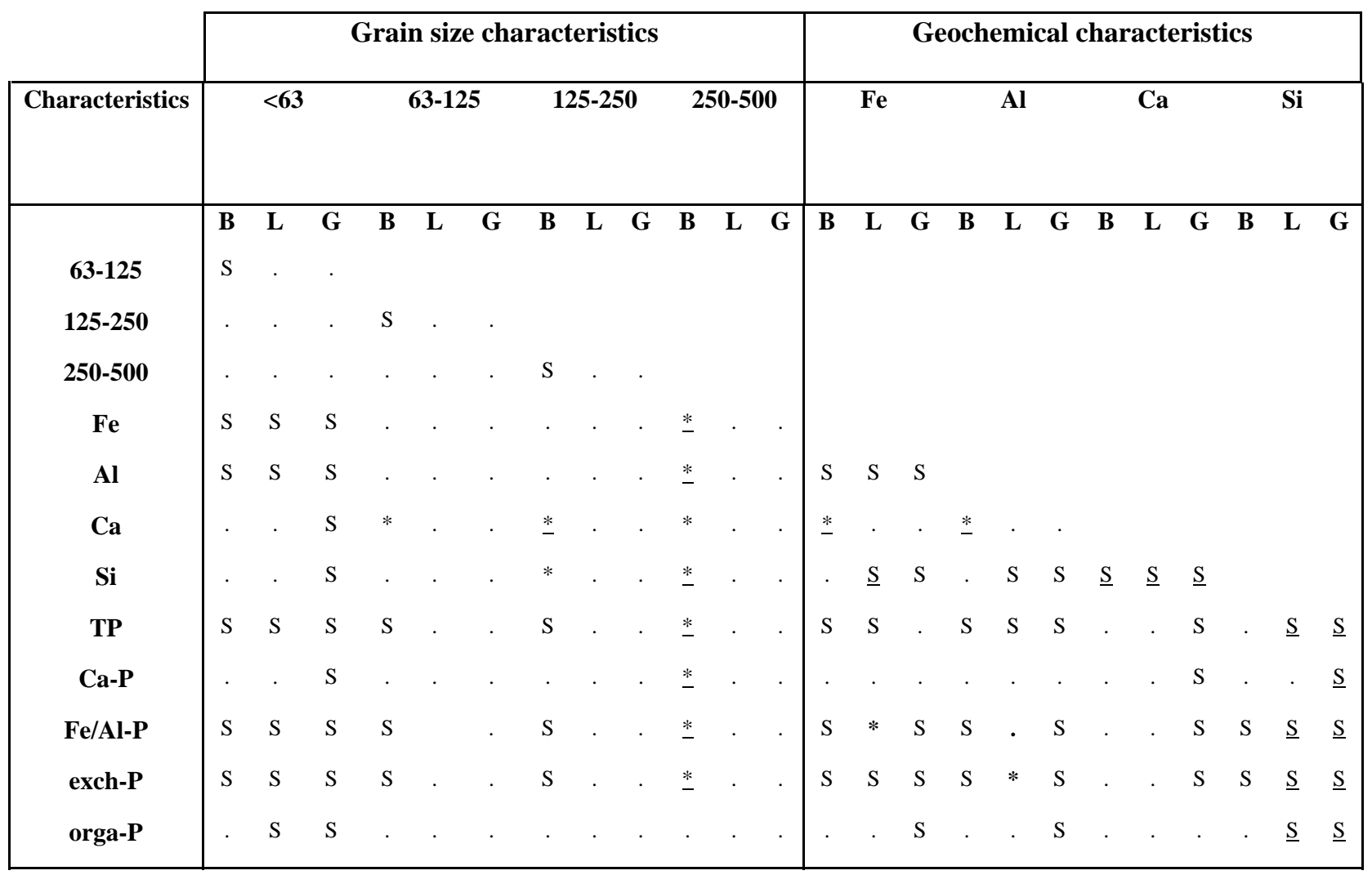

* : Regression very close to significant 
Table 4. Fe/Al-P and exch-P concentrations $\left(\mu \mathrm{mol} \mathrm{g}^{-1}\right)$ in the fine fraction $(<63 \mu \mathrm{m})$ in the Bay of Seine, the Loire and Gironde estuaries. Comparison of direct measurement by chemical extraction, and indirect evaluation from the slopes of regression lines.

\begin{tabular}{ccccc}
\hline SITE & \multicolumn{2}{c}{ Fe/Al-P } & \multicolumn{2}{c}{ exch-P } \\
\hline & Direct & Indirect & Direct & Indirect \\
\hline Bay of Seine & $4.4 \pm 0.3^{*}$ & $200 \pm 25$ & $2.1 \pm 0.1^{*}$ & $65 \pm 12$ \\
& $7.3 \pm 1^{* *}$ & & $4.6 \pm 0.2^{* *}$ & \\
Loire & & & \\
Stations L19, L20, L21, & $6.3 \pm 0.9$ & $6.8 \pm 1$ & $6.1 \pm 0.8$ & \\
L24, L26 & & & \\
Gironde & & & \\
Stations G8, G9, G10, G11 & & & \\
& & & & \\
& & & & \\
& & & & \\
\end{tabular}

* Stations S3, S7, S12

** Stations S10, S15, S16, S17 
Figure 1. Map of surveyed areas and location of sampling stations. A: The Bay of Seine ; B: The Loire estuary ; C: The Gironde estuary. The terms « upper », « lower » and « outer » refer to Meybeck et al. (1988) and Jouanneau and Latouche (1981).

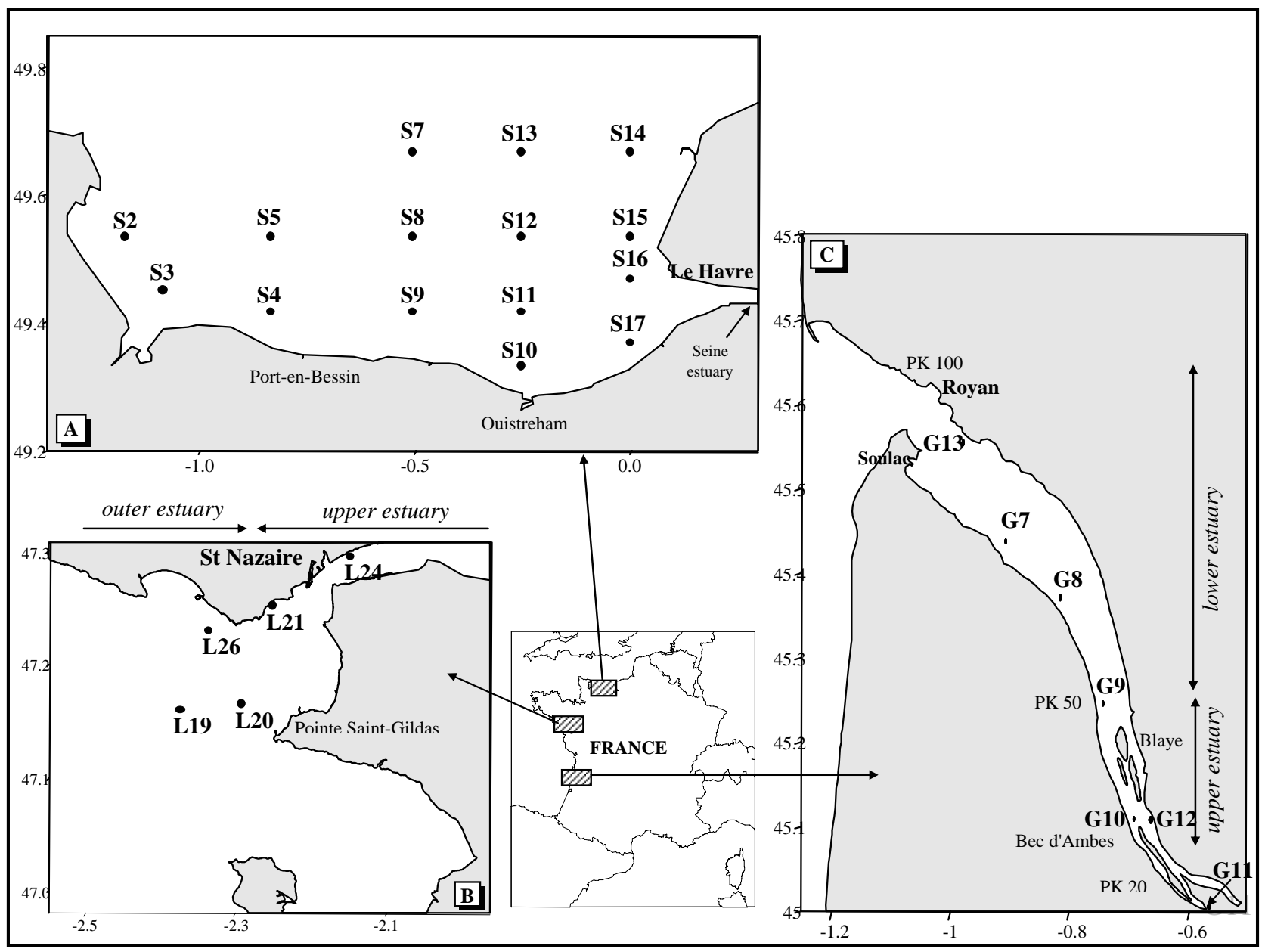


Figure 2: Distribution of phosphorus forms (exch-P + Fe/Al-P (NAIP), Ca-P) in sediment grain size fractions from the Bay of Seine.

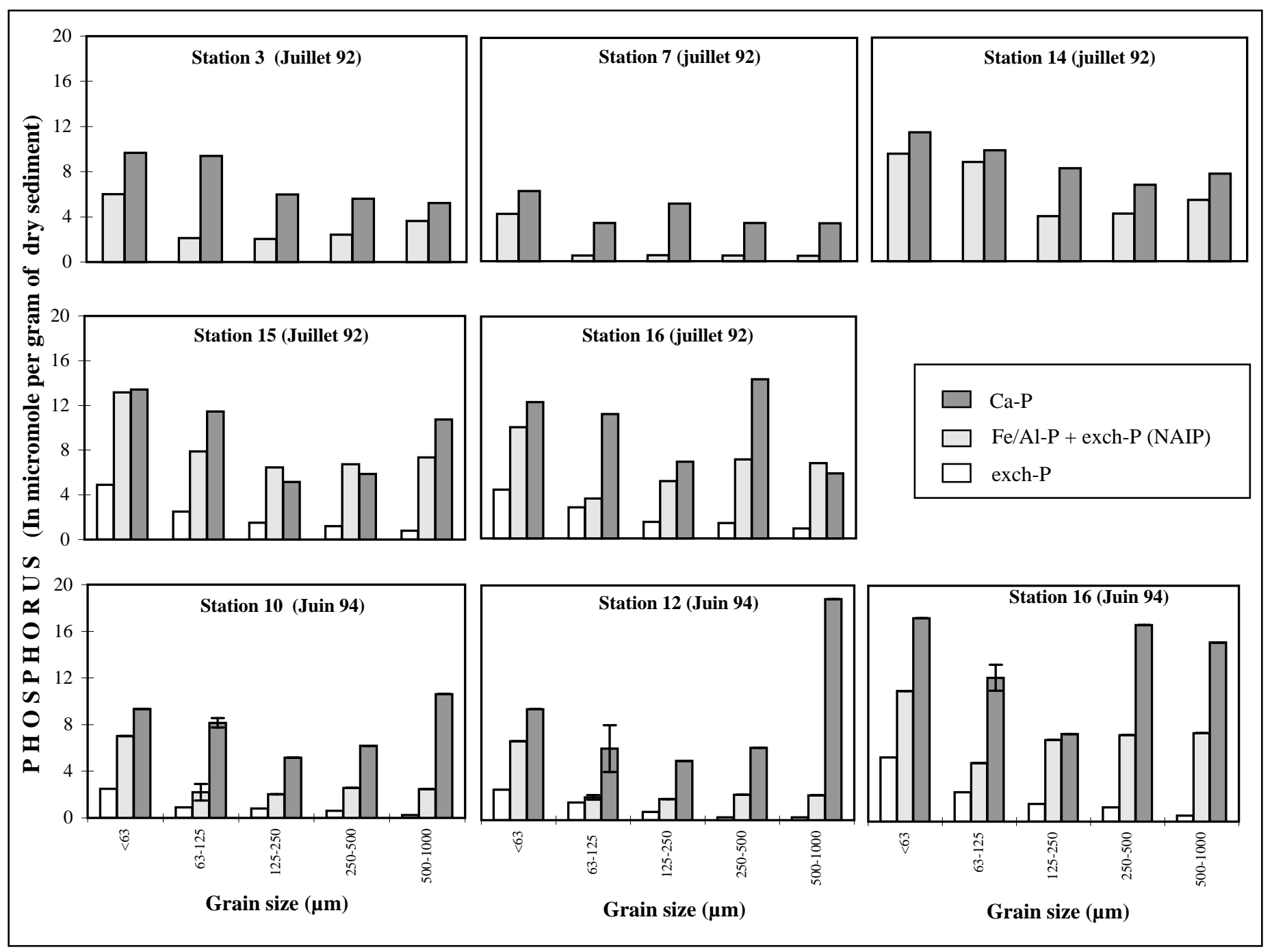


Figure 3: Relationships between phosphorus forms or major elements (micromole per gram) and percent of fine fraction $(<63 \mu \mathrm{m})$. Plots of Ca-P (A), Ca (B), Fe/Al-P (C), Fe (D), exch-P (E) and orga-P (F) versus percent of fraction lower than $63 \mu \mathrm{m}$. Square: Bay of Seine; triangle: the Loire estuary; circle: the Gironde estuary
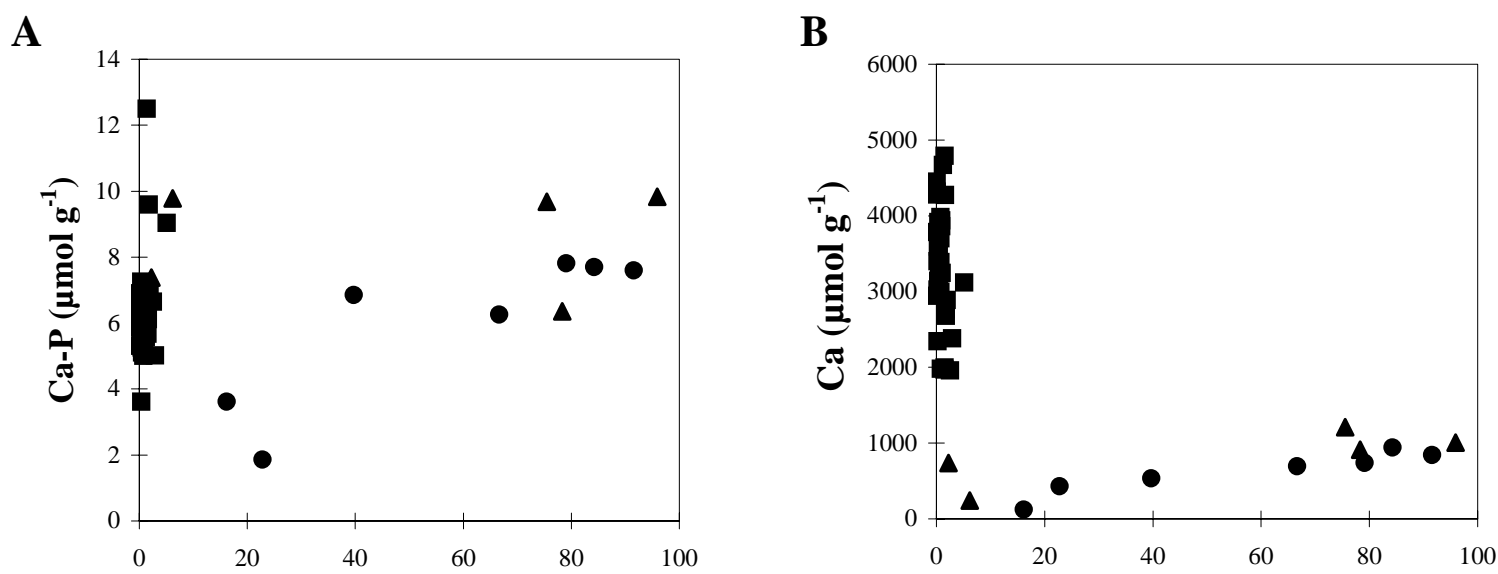

C

$\mathbf{D}$
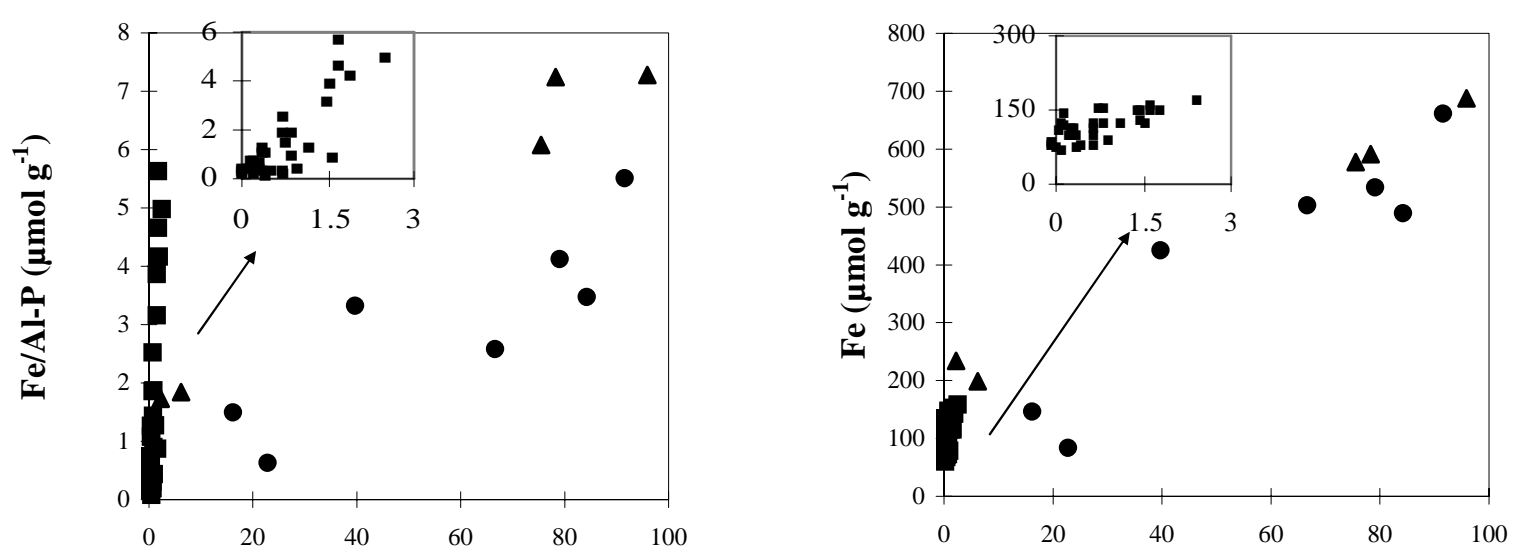

$\mathbf{E}$

$\mathbf{F}$
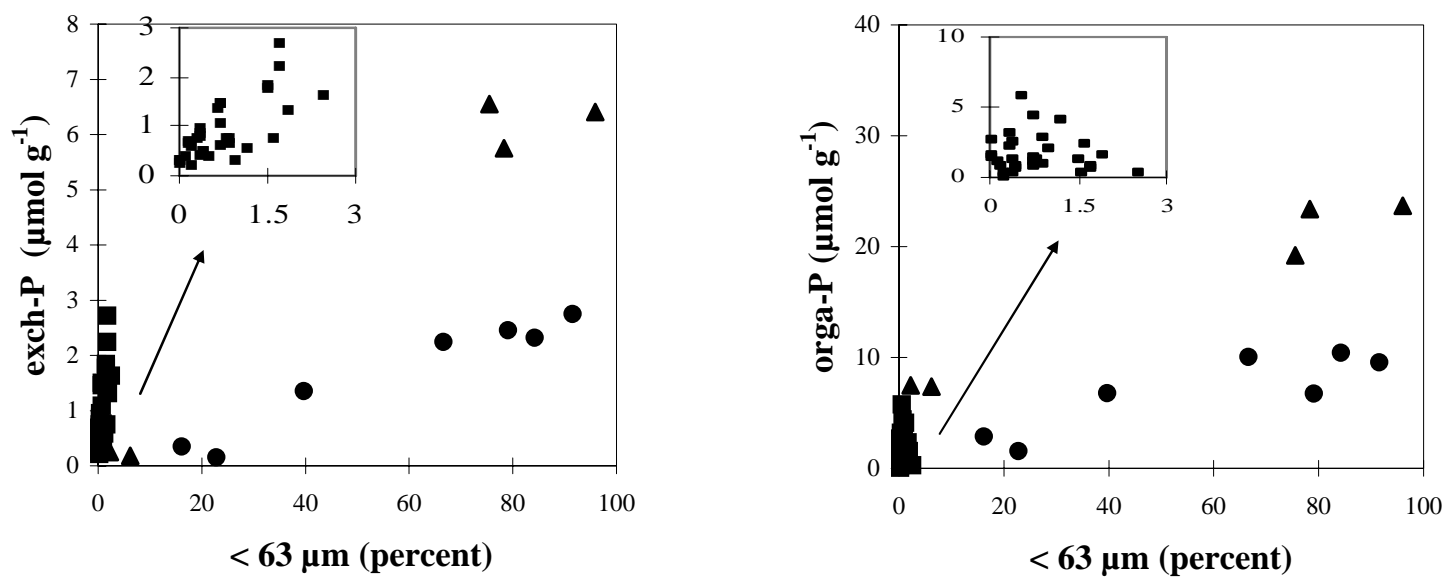
Figure 4 : Relationships between phosphorus forms (micromole per gram) and sediment characteristics (percent). Square: Bay of Seine; triangle: The Loire estuary; circle: The Gironde estuary . The coarser sediments in each site are identified by open symbols, according to their percentage of fractions $<125 \mu \mathrm{m}$ : Bay of Seine $<4 \%$; Loire $<6 \%$; Gironde $<12 \%$

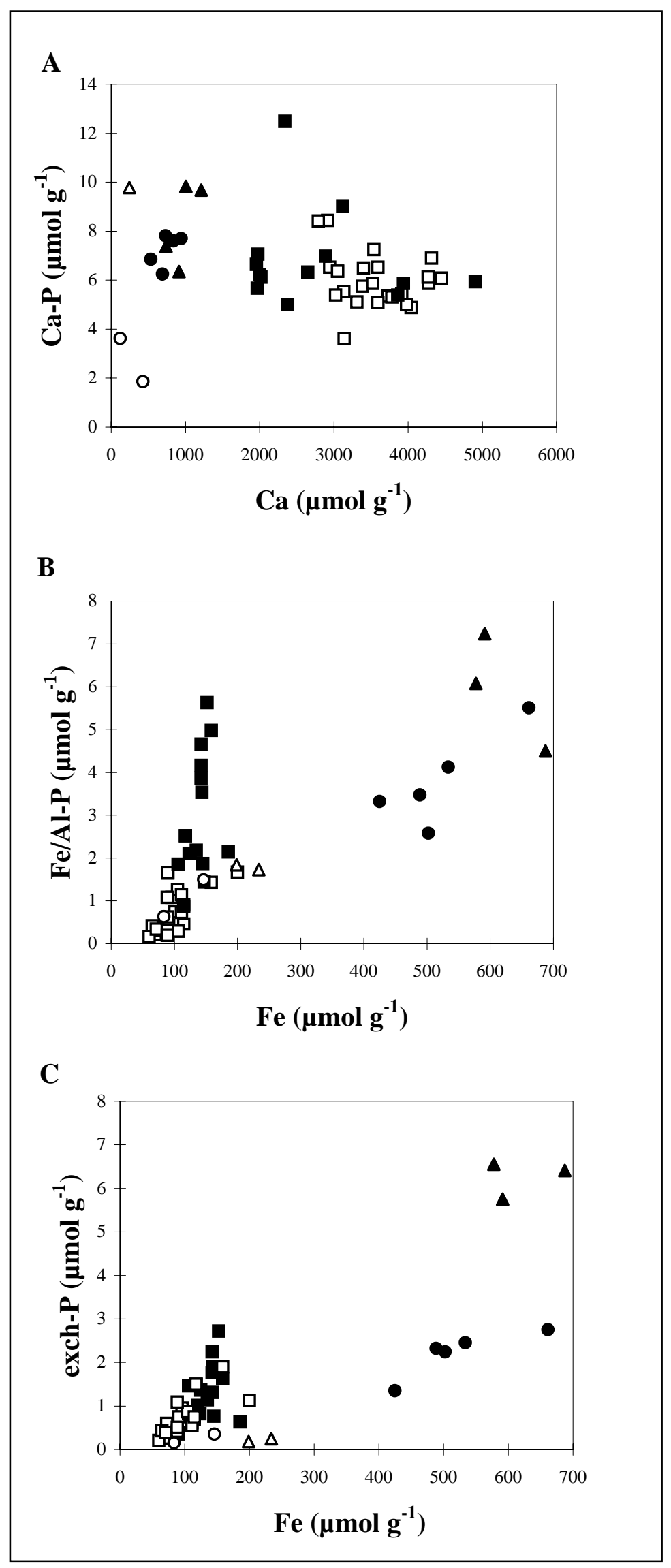

